EGU2020-22403

https://doi.org/10.5194/egusphere-egu2020-22403

EGU General Assembly 2020

(c) Author(s) 2021. This work is distributed under

the Creative Commons Attribution 4.0 License.

\title{
Six Underground Laboratories (ULs) Participating in the Baltic Sea Underground Innovation Network
}

\author{
Mats Ohlsson ${ }^{1}$, Jari Joutsenvaara ${ }^{2}$, Marcus Laaksoharju ${ }^{1}$, and Eija-Riitta Niinikoski \\ ${ }^{1}$ Swedish Nuclear Fuel and Waste Management Co., Solna, Sweden \\ ${ }^{2}$ University of Oulu, Finland
}

Baltic Sea Underground Innovation Network, BSUIN, consist of six participating Underground Laboratories (ULs) located in countries surrounding the Baltic Sea [http://bsuin.eu]. The BSUIN is a three-year project funded by the EU Interreg Baltic Sea Region Programme.

The aim of the BSUIN project is that the participating ULs will find new or expand the current use of underground laboratories to enhance the power of innovation and regional development. The project focus on the characterisation of the geological and technical settings of the ULs, health and safety issues, and various aspects to build and support innovation and the formation of a permanent network of Underground Laboratories.

The BSUIN ULs consist of old mines or purpose-built underground facilities. The ULs are used for research concerning e.g. environmental, geoenergy, geotechnology, physics, material science and natural sciences. Education, events, tourism and farming is also activities hosted by ULS.

We will present the underground laboratories of the BSUIN network:

- Äspö Hard Rock Laboratory, Oskarshamn, Sweden [http://www.skb.com/research-andtechnology/laboratories/the-aspo-hard-rock-laboratory/],

- Forschungs- und Lehrbergwerk - Research and Eduction Mine "Reiche Zeche", Freiberg, Germany [http://www.besucherbergwerk-freiberg.de/],

- Callio Lab in Pyhäsalmi mine, Pyhäjärvi, Finland [calliolab.com/callio-lab],

- KGHM S.A. mining company, Poland, together with their research organisation KGHM CUPRUM which proposes the construction of ULs located in one of the KGHM's deep copper [http://www.cuprum.wroc.pl/],

- The Low-Background underground laboratory of Khlopin Institute, St Petersburg, Russia [http://www.khlopin.ru/en/],

- Ruskeala Marble quarry and Geopark in Sortavala, Karelia, Russia. [http://ruskeala.info/en]. 